\title{
Instructional Supervisory Practices of Headteachers and Teacher Motivation in Public Basic Schools in Anomabo Education Circuit
}

\author{
Kweku Esia-Donkoh ${ }^{1}$ \\ Stella Baffoe ${ }^{2}$ (D) \\ ${ }^{1,2}$ University of Education, Winneba, Ghana \\ Email:ke_donkoh@yahoo.com
}

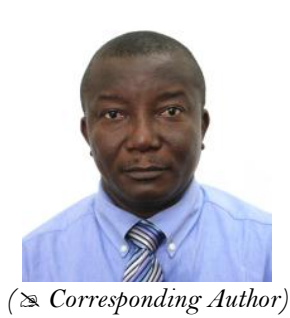

\begin{abstract}
The study examined the supervisory practices of headteachers and how these supervisory practices relate with teacher motivation in public basic schools in the Anomabo Education Circuit of the Mfantseman Municipality in the Central Region of Ghana. Quantitative approach of the cross-sectional survey design was adopted. Using purposive and stratified random sampling techniques, 69 respondents, made up of 15 headteachers and 54 teachers were used for the study. Two sets of questionnaire (one each for headteachers and teachers) were used to collect data. A test-re-test method was used and to establish the reliability of the instruments, and correlation coefficients of 8.45 and 8.72 were obtained for headteachers and teachers questionnaires respectively. The data obtained were analysed using mean, standard deviation, and Pearson Product Moment Correlation. The results indicated that headteachers in the Anomabo Education Circuit often used all the instructional supervisory practices outlined in the study and they performed above average. However, orientation of new teaching staff was the dominant supervisory practice among the headteachers while the least practiced was provision of in-service training for teachers. Generally, teachers in public basic schools in the Circuit were highly motivated, and there was a statistically significant positive but weak relationship between headteachers' supervisory practices and teacher motivation. The study concluded that pupils' performance had not been encouraging even though the teachers were adequately motivated. It was therefore recommended among others, that, the Mfantseman Municipal Directorate of Ghana Education Service should organize regular in-service training programmes for headteachers in public basic schools in the Anomabo Education Circuit to improve their skills to effectively balance and practice their instructional supervisory practices to enhance very high teacher motivation.
\end{abstract}

Keywords: Instructional supervision, Practices, Headteachers, Teachers, Motivation.

Citation | Kweku Esia-Donkoh; Stella Baffoe (2018). Instructional Supervisory Practices of Headteachers and Teacher Motivation in Public Basic Schools in Anomabo Education Circuit. Journal of Education and e-Learning Research, 5(1): 43-50.

History:

Received: 13 December 2018

Revised: 2 February 2018

Accepted: 5 February 2018

Published: 6 February 2018

Licensed: This work is licensed under a Creative Commons

Attribution 3.0 License $(\mathrm{ccc}) \mathbf{B Y}$

Publisher:Asian Online Journal Publishing Group
Contribution/Acknowledgement: Both authors contributed to the conception and design of the study.

Funding: This study received no specific financial support.

Competing Interests: The authors declare that they have no conflict of interests.

Transparency: The authors confirm that the manuscript is an honest, accurate, and transparent account of the study was reported; that no vital features of the study have been omitted; and that any discrepancies from the study as planned have been explained.

Ethical: This study follows all ethical practices during writing.

\section{Contents}

1. Introduction 


\section{Introduction}

It is acknowledged that education is very instrumental and an essential agent in national development. As a result improving the quality of education, especially at the basic education level, has become the concern of all nations. Kotirde and Yunos (2014) substantiate this by indicating that the concern for quality has been at the core of the motivating forces for reforms in education, and achieving quality in education has increasingly become crucial in strategic improvement plans of developing countries. These reforms include Millennium Development Goals (MDG); Sustainable Development Goals (SDG); Education for All (EFA); and Education 2030 Agenda which reflects the fourth SDG (De Grauwe, 2016). It is for this reason that educational quality assurance is a matter of accountability and national interest (McLoughlin and Visser, 2003). Achieving educational aims and providing quality basic education greatly depends on the significant role played by teachers in determining the nature of education received in schools (Gwaradzimba and Shumba, 2010). This means that stakeholders of education need to ensure the performance of tasks by teachers to the best of their abilities in order to offer quality education to students.

One of the important aspects of educational management is instructional supervision which may be defined as the process of bringing about improvement in the teaching-learning process through a network of cooperative activities and democratic relationship of persons concerned with teaching and learning, and it is considered as an important activity to achieve an effective education system (Oyewole and Ehinola, 2014). It is mainly concerned with pupil learning in the classroom, and it is seen as a collaborative effort which involves a set of activities structured with the aim of improving the teaching and learning process (Aguba, 2009; Archibong, 2013). This means that instructional supervision is characterised by all those activities which are undertaken to help teachers maintain and improve their effectiveness in the classroom. However, it is not designed to find faults or punish, but rather, to see the teacher as a colleague and work together to enhance teaching and learning in schools. Instructional supervision is considered an essential activity in the management and administration of educational institutions because it ensures the quality of educational organizations, and draws together disconnected elements of instruction into whole-school actions (Glickman et al., 2009). Arong and Ogbadu (2010) share this view by commenting that instructional supervision provides opportunities for schools to be effective for improving professional development of teachers to effectively manage teaching and learning processes. Similarly, Okendu (2012) postulates that instructional supervision enhances teaching and learning through proper guidance and planning, and devising ways to improve teachers' professional knowledge, skills and experiences to make them creative in instructional processes. From the foregoing, it could be said that the general consensus from literature is that instructional supervision aims at improving practice, improving student learning achievement, reflection, and improving the overall school and these goals can be achieved when teachers learn with and from one another (Harrison and Killion, 2007). It is therefore deduced that to promote quality teaching and learning in basic schools in Ghana, stakeholders need to pay attention to instructional supervision.

Researchers and instructional supervision experts have identified different models that supervisors like head teachers of public basic schools apply in their supervisory practices. In selecting a supervisory model however, Glickman (2002) maintains that it is imperative for a supervisor to consider teachers' level of experience in instructional practices, their developmental level, and the contexts within which a supervisor works. Some of these models are peer supervision, clinical supervision, developmental supervision, and differentiated supervision theory.

Sergiovanni and Starratt (2007) explain that in peer supervision, teachers agree to work together for their own professional development. Hence, teachers engage in supervisory tasks by visiting each other's class to learn and to provide help, critique each other's planning, examine together samples of students' work, and assess the quality of teaching and learning students receive. Clinical supervision refers to face-to-face contact with teachers with the intent of improving instruction and increasing professional growth (Sergiovanni and Starratt, 2007). This means that in clinical supervision, supervisors work with teachers in a collaborative way, and provide expert assistance to teachers with the view of improving instruction in the classroom. Hence, it opens up channels of communication, provide feedback to teachers about their teaching in an objective non-judgmental manner and to dialogue about teaching and learning.

According to Thomas (2011) clinical supervision has five stages (pre-observation conference, classroom observation, analysis and interpretation of data from the observation, planning for post-observation conference, and supervisor's analysis of the post-observation conference) and this is why Sullivan and Glanz (2009) argue that clinical supervision is focused on the improvement of instruction by means of systematic cycles of planning, observation, and intensive intellectual analysis of actual teaching performance in the interest of rational modification.

With the developmental model, Bernard and Goodyear (2009) postulate that the progress of teachers is seen in different stages or levels continuing to develop more complex skills which require supervisors to adopt different styles, strategies and approaches. In view of this, Glickman et al. (2009) identified four approaches of the developmental model as directive control, directive informational, collaborative, and non-directive styles that can be utilised to best meet the needs of teachers.

Sergiovanni (2009) asserts that "a differentiated system of supervision which is more in tune with growth levels, personality characteristics, needs and interests, and professional commitments of teachers is needed" ( $p$. 281). Glathorne (2000) further explains that differentiated supervision is an approach to supervision where teachers are given options on the kinds of supervisory methods they will like to adopt. The model assumes that all teachers should involve themselves in teacher evaluation, staff development and informal observation to improve instruction, irrespective of their experience and competence. It could be inferred from the description that differentiated supervision is not a different type of supervision model, but rather the use of an approach based on different supervisory models considering the supervisees and the appropriateness of the model. Glathorne (2000) therefore argues that it is a model that involves clinical supervision, co-operative development and self-directed development aimed at working towards teachers' growth.

The differentiated supervision was considered for the study because of the diversity of the teachers which may make it inappropriate for a "one-size-fit-all" approach to supervision. The teachers have different levels of 
experience, personal traits, academic background, and work in varied social contexts. With this, it is pertinent that the teachers are provided an opportunity to choose from a number of approaches that would prove effective in their peculiar setting and situations. All models of supervision are relevant in particular situations, so the supervisor (headteacher) needs to be abreast with each model so that they could be adopted when the need arises.

Teacher motivation is considered a crucial issue because teachers are expected to impart knowledge and skills to learners (Mertler, 2002). As a result, the impact of motivation on employee performance and commitment has been discussed severally among organisational behaviour experts and researchers. Motivation, which has been defined in so many ways is referred to as the reasons or factors that encourage or make people behave in a particular way (Nelson and Quick, 2012). Motivation is therefore a driving force that induces an individual to take some actions to achieve set goals. Pinder (2014) describes motivation as the intrinsic and extrinsic elements that influence an individual to act in certain ways or take certain actions.

According to Herzberg (1987) Motivation Hygiene Theory (also known as the Two Factor Theory), there are certain factors at the workplace that result in job satisfaction of the workforce. These are referred to as motivators. A separate set of factors known as hygiene factors, also cause dissatisfaction among workers. Examples of motivators according to Herzberg are achievement, recognition, work itself, responsibility, advancement and growth. Examples of hygiene factors include policy, supervision, relationship, work conditions, salary, and security which must be satisfied if they are not to have negative influence on the employees.

Malik et al. (2010) argue that motivation significantly determines education achievements and outcomes. This implies that objectives of educational institutions like any other organisation can be achieved when the employees are well motivated. Motivated teachers are therefore more satisfied and this brings about higher performance than those who are less motivated (Iwu et al., 2013). The finding of a study by Mustafa and Othman (2010) that a positive relationship exists between motivation and teacher performance substantiates these assertions. Furthermore, it is argued that the level of staff turnover may reduce to some extent if the staff are motivated to perform their tasks (Nahavandi et al., 2014). This means that motivation helps to reduce staff attrition by improving employees' desire to maintain membership in an organization for long.

Literature reveals several supervisory practices of the headteacher. One of such major supervisory practices is lesson observation (Okumbe, 1999). However, Gaziel (2007) established that majority of principals neither make visits to classrooms to observe teachers' lessons nor give feedback to teachers after class observations. Musungu and Nasongo (2008) found out from a study that the headteachers' instructional practices included checking lesson books, schemes of work, records of work covered, and attendance. It has been revealed that most principals check schemes of work, teachers' record of work, protect students' instructional time through punctuality (Sabitu and Ayandoja, 2012; Samoei, 2014). Panigrahi (2012) also found that head teachers focused more on work records than on practical work done by teachers while Kramer et al. (2005) observe that distributing literature about instruction, in-service training in the form of workshops, conferences, and seminars form the supervisory practices of head teachers and these equip teachers with expertise as a form of professional development. On orientation of new staff, Samoei (2014) observed that $66.7 \%$ of headteachers always orient new teaching staff in their schools. In another study, Muoka (2007) observed that principals carry out inductions of staff and orientation of school programme.

Although motivation, which is closely related to job satisfaction, could be said to be complex, and affected by many factors, it could be measured to determine if employees are motivated or demotivated by finding out whether they are satisfied with factors such as interpersonal relationship, opportunities for promotion, work environment, social recognition, and remuneration and conditions of service (Garudzo-Kusereka, 2009). Thus, the levels of satisfaction of teachers reflect their motivation levels.

Different levels of teacher motivation have been established by researchers. For instance, it was revealed that generally, teachers in Zimbabwean Secondary Schools had low levels of motivation (Garudzo-Kusereka, 2009). Other low levels of motivation among teachers have been established through research (De Jesus and Conboy, 2001; Lethoko et al., 2001). Mertler (2002) however found out in the United States that $77 \%$ of the survey respondents were generally satisfied and motivated by performing their duties as teachers. Again, Munyengabe et al. (2017) established from a study that levels of motivation of lecturers in Chinese University was satisfactory. Dorji (2014) also concluded from a study that teachers in government and middle secondary schools in Thimphu were moderately motivated.

On factors affecting motivation, Onyambu (2014) found out that teachers in Masaba South District of Kenya were highly motivated with recognition given them, potential for professional growth, and internal relationship with colleague teachers. Similarly, Dorji (2014) study revealed that the top four factors of motivation indicated by teachers in government and middle secondary schools in Thimphu were professional growth, professional development, clear feedback from principals, salary, and recognition and appreciation of work. The findings from Garudzo-Kusereka (2009) study indicated that teachers in Zimbabwean secondary schools were satisfied with their motivation in terms of interpersonal relationship even though they were not satisfied with their motivation considering work condition, organizational practices, opportunities for positional advancement and participation in professional development programmes, and autonomy in performing their duties as teachers.

Researchers have documented the relationship between supervisory practices and motivation. In a study by Ghavifekr and Ibrahim (2014) it was revealed that Heads of Department's supervisory practices related to the teachers' motivation and subsequently led to their job performance. This makes Yukl (2010) to postulate that an instructional supervisor must have the competency and ability to encourage and motivate subordinates to work together to achieve and perform better. Therefore, teachers who are motivated by the instructional supervisory practices of their headteachers will be encouraged perform very well. Wanzare (2012) study established that instructional supervisory practices significantly relate with motivation, and concluded that school heads are expected to provide the right motivation and stimulation for staff through their instructional supervisory role. They are to use supervisor-teacher friendly methods, and move from the traditional method of control and authoritarianism to more cooperative and collaborative practices.

The Mfantseman Municipality, where Anomabo Education Circuit is found, has witnessed poor academic performance among pupils in recent times. records In 2010 for instance, 1330 (47.2\%) of the 2820 candidates 
presented for Basic Education Certificate Examination (BECE) in the Municipality passed, indicating that 52.8\% of the candidates could not gain admission into Senior High Schools (SHS). In the same year, six schools had zero per cent (Mfantseman Municipal Education Directorate, 2016). In 2011, performance reduced to 36.8\% pass rate, and 11 schools had zero per. The pass rates in the BECE in 2013 and 2015 were $48.2 \%$ and $53.2 \%$ respectively (MMED, 2016). The performance of pupils in public basic schools in the Anomabo Education Circuit had also been very poor since $2010 \ldots$.

The rate of failure among the pupils has become an issue of concern to stakeholders of education in the Municipality, and specifically, in the Circuit. Oduro (2008) found out that poor supervision of teachers one of the major causes of poor academic performance among pupils in basic schools in Ghana. Besides, Kageha (2008) also argues that instructional supervision of teachers is linked to their motivation. Therefore, it could be argued that poor academic performance of pupils public basic schools in the Anomabo Education Circuit could be attributed to ineffective instructional supervision practices of headteachers, and demotivation of teachers.

Headteachers in the Anomabo Education Circuit, like those in the other circuits of the Mfantseman Municipality, are expected to perform instructional tasks such as lesson observation, orientation of new staff, monitoring punctuality and regularity, checking school records, and conducting in-service training. The aim is to ensure effective performance of teachers, improvement in pupils' academic performance, and generally, the achievement of school and educational goals. However, it is not clear whether these supervisory practices relate with teacher motivation in the Anomabo Education Circuit since it appears there is no research evidence on the relationship between headteachers' supervisory practices and teacher motivation. These reasons informed the conduct of this study.

The following research questions were formulated to guide the study:

1. What supervisory practices do headteachers of public basic schools in the Anomabo Education Circuit exhibit?

2. What is the level of motivation of teachers in public basic schools in the Anomabo Education Circuit?

3. What is the relationship between headteachers' supervisory practices in public basic schools in the Anomabo Education Circuit and teacher motivation?

The findings of the study will contribute to effective implementation of supervisory practices of headteachers, and improve teacher motivation in the Anomabo Education Circuit. It is hoped that the findings of the study will make headteachers to be aware of their supervisory practices and reinforce those practices that are likely to enhance teacher motivation. To the teachers, the findings of the study would throw more light on the instructional supervisory practices that headteachers are expected to carry out in their schools to boost their motivation. This will encourage the teachers to be cooperative during instructional supervision for better results. Furthermore, the findings of the study will inform the Mfantseman Municipal Directorate of the Ghana Education Service on areas of supervision that require attention when designing programmes for internal supervision in public basic schools, and organising effective in-service programs for headteachers and teachers on matters of instructional supervision and motivation. Again, the findings of the study will benefit the pupils in their performance through improved head teachers' supervisory practices and teacher motivation. it will also serve as the basis for further research in basic schools in the Mfantseman Municipality.

\section{Methodology}

The study adopted the cross sectional survey design because it helps to obtain information about the occurrence, distribution, and interrelations of variables within a population where data are usually gathered through self-reporting (Polit and Beck, 2010). This was in line with the purpose of the study which sought to describe the supervisory practices of head teachers, teacher motivation, and the relationship between these two variables through self-report of the respondents. The quantitative approach which involves statistical analysis and relies on numerical evidence to examine relationships between variables and draw conclusions (Burns and Grove, 2011) was employed because the study sought to investigate the relationship between headteachers' supervisory practices and teacher motivation. The population for the study consisted of all headteachers and teachers in public basic schools in the Anomabo Education Circuit of the Mfantseman Municipality, and the target population was made up of headteachers and teachers who had worked in their present schools for at least two years. The target population was 232 made up of 15 headteachers and 217 teachers.

A sample size of 69 participants (15 headteachers and 54 teachers) representing about $30 \%$ of the target population was deemed appropriate and used for the study since it is suggested that a sample size of $10 \%$ to $30 \%$ of the target population is representative in quantitative studies (Asamoah-Gyimah and Duodu, 2007). The purposive and stratified sampling techniques were used to select the sample for the study. All 15 headteachers (who had spent at least two years at their current school) were purposively sampled for the study because the study sought to examine the supervisory practices of headteachers. Hence, their views were crucial in gaining an understanding of this variable. The teacher target population was put into two strata by sex and a proportionate sampling procedure was followed to select from each stratum so that the sample represented the population. The male target population was $59.0 \%$ and that of the females was $41.0 \%$. Therefore, out of the 54 teachers randomly selected, 32 were males and 22 were females.

Two sets of questionnaire (one each for headteachers and teachers) were used to collect data because questionnaires are appropriate in obtaining data on perceptions, attitudes, knowledge and experiences of people (Parahoo, 2006; Orodho, 2009). Since the study sought to investigate instructional supervisory practices of headteachers and how these practices relate with teacher motivation in public basic schools in the Anomabo Education Circuit, the use of the questionnaires which were in three sections, was deemed appropriate. The first section of the questionnaires collected information on the personal characteristics of the respondents, the second section included items on headteachers' supervisory practices while the third section dwelt on teacher motivation. Sections two and three of the questionnaire were measured on a 5-point Likert scale.

The questionnaires were pre-tested in three randomly selected public basic schools in the Yamoransa Education Circuit in the Mfantseman Municipality. Through the test-retest (with two weeks interval) approach, 
the Pearson coefficient was calculated to compare the two sets of data for the questionnaires. The resultant coefficients were 8.45 for headteachers' questionnaire and 8.72 for teachers' questionnaire. These coefficients implied the items in the questionnaire were reliable since a good reliability is indicated by a coefficient greater than 0.8 (Jones and Rattray, 2010).

\section{Results and Discussion}

In analysing the data, mean, standard deviation, and Pearson Correlation were used.

\subsection{Supervisory Practice(s) Exhibited by Headteachers of Public Basic Schools in Anomabo Education Circuit}

The first research question was to determine the supervisory practices of headteachers of public basic schools in the Anomabo Education, Circuit. In analysing this research question, means were used to determine the levels of instructional supervisory practices of the headteachers. These levels were: 0.1-1.0 (never); 1.1-2.0 (rarely); 2.1-3.0 (sometimes); 3.1-4.0 (often); and 4.1-5.0 (always). Data in Table 1 explains the supervisory practices used by the headteachers.

Table-1. Descriptive Statistics of Supervisory Practices of Headteachers

\begin{tabular}{l|l|c|c|c|c}
\hline Supervisory Practices & N & Minimum & Maximum & Mean & Std. Deviation \\
\hline Orientation of new Teaching Staff & 69 & 3 & 5 & 3.74 & 0.61 \\
\hline Checking Teacher's Record of Work & 69 & 3 & 5 & 3.46 & 0.57 \\
\hline Provision of In-service Training & 69 & 2 & 5 & 3.33 & 0.70 \\
\hline Lesson Observation & 69 & 2 & 5 & 3.64 & 0.63 \\
\hline Monitoring Punctuality \& Regularity & 69 & 3 & 5 & 3.67 & 0.55 \\
\hline
\end{tabular}

The data in Table 1 shows that headteachers of public basic schools in the Anomabo Education Circuit often exhibited all the supervisory practices outlined in this study. This stems from the mean range of 3.33 and 3.74 obtained for all the five instructional supervisory practices. A 5-point Likert scale was used to collect data on instructional supervisory practices of headteachers. This implies a mean (average) score of 3.0. The deduction is that headteachers' practice of the supervisory tasks was above average for all the tasks. However, orientation of new staff was dominant among the headteachers while provision of in-service training was least practiced in the schools. It is important to note that new teachers need to be assisted to be familiar with their tasks, work environment, the challenges they are likely to face, and how to address them. The findings of this study agree with those of Sabitu and Ayandoja (2012) and Samoei (2014) that most of supervisors check schemes of work, teachers' record of work, monitor teachers' punctuality, and check teachers' instructional records. The findings further substantiates that of Samoei (2014) that orientation of new teaching staff in their schools was dominant among head teachers. However, it disagrees with the findings of Okumbe (1999) that lesson observation was a foremost activity in the supervisory practices of the head teachers.

\subsection{Motivation Level of Teachers of Public Basic Schools in the Anomabo Education Circuit}

The second research question was aimed at determining the level of motivation of teachers in public basic schools in the Anomabo Education Circuit in relation to remuneration and conditions of service, work environment, interpersonal relationship, opportunities for promotion, and social recognition. Interpretation of means as suggested by Jamil (2012) and cited by Mohd et al. (2013) was adopted for the interpretation of levels of teacher motivation in the Anomabo Education Circuit. The numerical mean values and their interpretations used are shown in Table 2.

Table-2. Mean Ranges and Interpretations for Teacher Motivation

\begin{tabular}{l|l}
\hline Mean Range & Interpretation \\
\hline $1.00-1.80$ & Very Low \\
\hline $1.81-2.60$ & Low \\
\hline $2.61-3.40$ & Moderate \\
\hline $3.41-4.20$ & High \\
\hline $4.21-5.00$ & Very High \\
\hline Source: Jamil (2012) cited in Mohd et al. (2013)
\end{tabular}

The results of the level of motivation of teachers in public basic schools in the Anomabo Education Circuit are presented in Table 3.

Table-3. Descriptive Statistics of Levels of Teacher Motivation

\begin{tabular}{l|c|c}
\hline Components of Motivation & Mean & Standard. Deviation \\
\hline Interpersonal Relationship & 4.68 & 0.72 \\
\hline Opportunities for Professional Growth & 4.47 & 0.83 \\
\hline Work Environment & 3.66 & 0.74 \\
\hline Recognition of Effort & 3.78 & 0.65 \\
\hline Remuneration and Conditions of Service & 2.36 & 0.78 \\
\hline Overall Teacher Motivation & 3.79 & 0.57 \\
\hline Source: Survey Data, 2016 & &
\end{tabular}

Source: Survey Data, 2016

The results in Table 3 show that teachers in public basic schools in the Anomabo Education Circuit had a very high motivation with interpersonal relationship $(\mathrm{M}=4.68, \mathrm{SD}=0.72)$, and opportunities for professional growth 
$(\mathrm{M}=4.47, \mathrm{SD}=0.83)$. They were also highly motivated with work environment $(\mathrm{M}=3.66, \mathrm{SD}=0.74)$, and recognition of effort $(\mathrm{M}=3.78, \mathrm{SD}=0.65)$. However, they had a low motivation with remuneration and conditions of service $(\mathrm{M}=2.36, \mathrm{SD}=0.78)$. The results also show that generally (overall), teachers in public basic schools in the Anomabo Education Circuit were highly motivated. This is seen from an overall mean of 3.79 and a standard deviation of 0.57. The findings seem to confirm the finding of Mertler (2002) that 77\% of teachers in the United States were generally satisfied and motivated by performing their duties, but contradicts Garudzo-Kusereka (2009) finding that generally, teachers in Zimbabwean secondary schools had low levels of motivation.

\subsection{Relationship between Headteachers' Supervisory Practices and Teacher Motivation in Public Basic} Schools in the Anomabo Education Circuit

To examine the relationship between head teachers' supervisory practices and teacher motivation, the Pearson Product Moment correlation was used, and the results are presented in Table 4. The guideline provided by Peck et al. (2008) that coefficients less than 0.5 represent a weak relationship, coefficients greater than 0.5 but less than 0.8 represent a moderate relationship, and coefficients greater than 0.8 but equal to 1.0 represent a strong relationship was followed.

Table-4. Pearson Correlation Matrix for Supervisory Practices and Motivation

\begin{tabular}{|c|c|c|c|c|c|c|c|c|c|}
\hline Variables & Mean & Std. Dev. & 1 & 2 & 3 & 4 & 5 & 6 & 7 \\
\hline Overall Sup. Practice & 3.57 & 0.47 & 1 & & & & & & \\
\hline \multirow{2}{*}{$\begin{array}{l}\text { Orientation of } \\
\text { Teaching Staff }\end{array}$} & 3.74 & 0.61 & 0.894* & 1 & & & & & \\
\hline & & & $(0.00)$ & & & & & & \\
\hline \multirow{2}{*}{$\begin{array}{l}\text { Checking Teacher's Record } \\
\text { of Work }\end{array}$} & 3.46 & 0.57 & $0.819^{*}$ & $0.709 *$ & 1 & & & & \\
\hline & & & $(0.00)$ & $(0.00)$ & & & & & \\
\hline \multirow{2}{*}{$\begin{array}{l}\text { Provision of In-service } \\
\text { Training }\end{array}$} & 3.33 & 0.70 & $0.816^{*}$ & $0.631 *$ & 0.787 * & 1 & & & \\
\hline & & & $(0.00)$ & $(0.00)$ & $(0.00)$ & & & & \\
\hline \multirow[t]{2}{*}{ Lesson Observation } & 3.64 & 0.63 & $0.865^{*}$ & $0.758 *$ & $0.585^{*}$ & $0.601^{*}$ & 1 & & \\
\hline & & & $(0.00)$ & $(0.00)$ & $(0.00)$ & $(0.00)$ & & & \\
\hline \multirow{2}{*}{$\begin{array}{l}\text { Monitoring Punctuality \& } \\
\text { Reg. }\end{array}$} & 3.67 & 0.55 & $0.435^{*}$ & $0.333^{*}$ & $0.032^{*}$ & 0.038 & $0.364 *$ & 1 & \\
\hline & & & $(0.00)$ & $(0.01)$ & $(0.80)$ & $(0.76)$ & $(0.00)$ & & \\
\hline \multirow[t]{2}{*}{ Teacher Motivation } & 3.79 & 0.57 & $0.362 *$ & 0.165 & $0.354^{*}$ & $0.278^{*}$ & $0.263^{*}$ & $0.352^{*}$ & 1 \\
\hline & & & $(0.00)$ & $(0.18)$ & $(0.00)$ & $(0.02)$ & $(0.03)$ & $(0.00)$ & \\
\hline
\end{tabular}

$\mathrm{n}=69$ * Correlation is significant at $\mathrm{p}<0.05$ (2-tailed) NB: P-values are in parentheses

The Pearson correlation results in Table 4 reveal that generally there was a weak but statistically significant positive relationship between headteachers' supervisory practices and motivation $(\mathrm{r}=0.362, \mathrm{p}=0.00,2$-tailed) at 0.05. The results further indicate that there was no statistically significant relationship between orientation of new staff and teacher motivation $(\mathrm{r}=0.165, \mathrm{p}=0.18,2$-tailed); there was a weak but statistically significant positive relationship between checking teacher's record of work and teacher motivation ( $\mathrm{r}=0.354, \mathrm{p}=0.00,2$-tailed); there was a weak but statistically significant positive relationship between provision of in-service training and motivation $(\mathrm{r}=0.278, \mathrm{p}=0.02,2$-tailed $)$; there was a weak but statistically significant positive relationship between lesson observation and motivation $(\mathrm{r}=0.263, \mathrm{p}=0.03,2$-tailed $)$; and there was a weak but statistically significant positive relationship between monitoring punctuality and regularity and teacher motivation $(\mathrm{r}=0.352, \mathrm{p}=0.00,2$-tailed). Based on these results, it is proven that headteachers' supervisory practices are essential in promoting teachers' motivation, and that except orientation of new staff, all the supervisory practices were important in enhancing teacher motivation in the Anomabo Education Circuit. This confirms the findings from a study conducted by Ghavifekr and Ibrahim (2014) that supervisory practices of Heads of Department related to teachers' motivation. it also substantiates Wanzare (2012) finding that supervisory practices significantly relate with motivation.

\section{Conclusions and Recommendations}

This study investigated the supervisory practices of headteachers and how they relate with teacher motivation in the Anomabo Education Circuit in the Mfantseman Municipality. The findings revealed that headteachers made use of all the supervisory practices identified, and that their practice of the supervisory tasks was above average for all the tasks. However, orientation of new teaching staff was predominantly practiced while provision of in-service training was the least practiced. The fact that the headteachers often made use of all the supervisory practices, and were found to be performing above average is a good indication that they were aware of the supervisory practices they had to undertake to ensure effective teaching and learning in their various schools.

It was established that the teachers had a very high motivation in relation to interpersonal relationship, and opportunities for professional growth. They were also highly motivated with work environment, and recognition of effort, but experienced a low motivation with remuneration and conditions of service. Generally, the teachers experienced a high motivation. It is however intriguing that even though the headeachers performed above average in terms of their instructional supervisory practices, and with highly motivated teachers, academic performances of the pupils in the Anomabo Education Circuit were not encouraging. One therefore wonders if other factors account for such poor performances in the Education Circuit. Perhaps, the level of motivation of teachers could still be improved to ensure effective performance if their welfare, conditions of service, training and other needs are made attractive. Headteachers of public basic schools in the Anomabo Education Circuit should therefore improve on their instructional supervisory practices to provide the needed motivation and stimulation for their teachers to excel. Headteachers must therefore see to it that their instructional supervisory practices are based on co-operation and collaboration of efforts with the teachers.

The results also showed a statistically significant positive but weak relationship between the supervisory practices of headteachers and teacher motivation. Except orientation of new staff, all the supervisory practices (checking teacher's record of work provision of in-service training, lesson observation, and monitoring punctuality and regularity) correlated significantly with teacher motivation. Interestingly, orientation of new staff which was a 
dominant supervisory practice of the headteachers, did not significantly contribute to teachers' motivation. It is therefore important for headteachers to keenly execute their supervisory tasks so that teachers will be motivated to do their work. Even though not all supervisory practices of hedteachers in public basic schools in the Anomabo Education Circuit significantly contributed to teachers' motivation, headteachers in the Education Circuit need to pay equal attention to all their supervisory tasks to achieve optimum motivation of teachers.

It is therefore recommended that, The Mfantseman Municipal Directorate of GES should organize in-service training programmes for the headteachers of public basic schools in the Anomabo Education Circuit to equip them with the appropriate knowledge and skills to effectively balance and practice the supervisory tasks that are most likely to increase teacher motivation. The Mfantseman Municipal Directorate of GES should also take care of the welfare, conditions of service, work environment, training and other needs of the teachers so that irrespective of their age, gender, academic qualification, and experience, they will be well motivated to do their work. Again, further research should be conducted on instructional supervisory practices of headteachers and teacher motivation in public basic schools in the Anomabo Education Circuit, and other Education Circuits in the Mfantseman Municipality to obtain a general information which will inform policy and practice to enhance effective instructional supervision and teacher motivation in the Municipality.

\section{References}

Aguba, C.R., 2009. Educational administration and management: Issues and perspectives. Enugu: Tons and Tons PDS Publishers.

Archibong, F.I., 2013. Instructional supervision in the administration of secondary education: A panacea of quality assurance. European Scientific Journal, 8(13): 15-27.

Arong, F.E. and M.A. Ogbadu, 2010. Major causes of declining quality of education in Nigeria administrative perspective: A case study of Dekina local government area. Canadian Social Science, 6(3): 61-76.

Asamoah-Gyimah, K. and F. Duodu, 2007. Introduction to research methods in education. Winneba: Institute for Educational Development and Extension (IEDE), University of Education, Winneba.

Bernard, J.M. and R.K. Goodyear, 2009. Fundamentals of clinical supervision. 4th Edn., Massachusetts: Allyn \& Bacon.

Burns, N. and S.K. Grove, 2011. Understanding nursing research - building an evidence-based practice. 5th Edn., Maryland Heights, Missouri: Elsevier Saunders.

De Grauwe, A., 2016. Educational planning for the 2030 agenda. International Institute for Educational Planning Letter, $32(2)$ : 1-3.

De Jesus, S.N. and J. Conboy, 2001. A stress management course to prevent teacher distress. International Journal of Education Management, 15(3): 131-137. View at Google Scholar | View at Publisher

Dorji, K., 2014. Motivating factors for teachers in government and middle secondary schools in Thimphu. Retrieved from http://www.202.144.157.211:8080/jspui/bitstream/1/.../Kuenzang\%20Dorji\%20PGDPA-1025.pdf [Accessed October 13, 2017].

Garudzo-Kusereka, L., 2009. Factors influencing the motivation of Zimbabwean secondary school teachers: An education management perspective. Retrieved from http://www.uir.unisa.ac.za/bitstream/handle/10500/1071/01Dissertation.pdf? sequence=2 [Accessed November 22, 2015].

Gaziel, H.H., 2007. Re-examining the relationship between principal's instructional educational leadership and student achievement. Journal of Social Sciences, 15(1): 17-24. View at Google Scholar | View at Publisher

Ghavifekr, S. and M. Ibrahim, 2014. Head of departments' instructional supervisory role and teachers' job performance: Teachers perceptions. Asian Journal of Social Sciences and Management Studies, 1(2): 45-56. View at Google Scholar

Glathorne, A.A., 2000. The principal as curriculum leader: Shaping what is taught and tested. Thousand Oaks, California: Corwin.

Glickman, C.D., 2002. Supervision of instruction: A developmental approach. Boston: Allan and Bacon.

Glickman, C.D., S.P. Gordon and J.M. Ross-Gordon, 2009. Super vision and instructional leadership: A developmental approach. 7th Edn., New York: Pearson Education Inc.

Gwaradzimba, E. and A. Shumba, 2010. The nature, extent and impact of the brain drain in Zimbabwe and South Africa. Acta Academica, 24(1): 209 241. View at Google Scholar

Harrison, C. and J. Killion, 2007. Ten roles for teacher leaders. Educational Leadership, 65(1): 74-77. View at Google Scholar

Herzberg, F.I., 1987. One more time: How do you motivate employees? Harvard Business Review, 65(5): 109-120.

Iwu, C.G., S.A. Gwija, H.O. Benedict and R.K. Tengeh, 2013. Teacher job satisfaction and learner performance in South Africa. Journal of Economics and Behavioral Studies, 5(12): 838-850. View at Google Scholar

Jones, M. and J. Rattray, 2010. Questionnaire design. 6th Edn., Oxford: Wiley-Blackwell.

Kageha, Z.A., 2008. The effect of motivation on teachers' performance and its Impact on K. C. S. E results: A case of Tiriki West Division, Vihiga District, Kenya. Unpublished M. Ed Project, Kenyatta University.

Kotirde, I.Y. and J.M. Yunos, 2014. The supervisor's role for improving the quality of teaching and learning in Nigerian secondary school education system. International Journal of Education and Research, 2(8): 53-60. View at Google Scholar

Kramer, C., P. Blake and F. Alba, 2005. A comparison of teacher attitudes toward supervision of instruction in selected high and low performance secondary schools of Puerto Rico. (Unpublished Doctoral Dissertation, Dowling College Brookhaven, New York.

Lethoko, M.X., J. Heystek and J.G. Maree, 2001. The role of the principal, teachers and students in restoring the culture of learning, teaching and service (COLT) in black secondary schools in Pretoria region. South African Journal of Education, 21(4): $311-316$. View at Google Scholar

Malik, E., R. Danish and A. Usman, 2010. Impact of motivation to learn and job attitudes on organizational learning culture in a public service organization of Pakistan. Lahore, Pakistan: University of the Punjab.

McLoughlin, C. and T. Visser, 2003. Global perspectives on quality in online higher education. World Conference on Educational Multimedia, Hypermedia and Telecommunications, 1: 253-256.

Mertler, C.A., 2002. Job satisfaction and perception of motivation among middle and high school teachers. American Secondary Education, 31(1): 43-53. View at Google Scholar

Mfantseman Municipal Education Directorate, 2016. Analysis of 2010-2015 basic education certificate examination. Saltpond: Examination Unit, Mfantseman Municipal Education Directorate.

Mohd, I., W. Yan, A. Jamil, H.A.H. Aida and N.M. Azalin, 2013. Supervision practices and teachers' satisfaction in public secondary schools: Malaysia and China. International Education Studies, 6(8): 92-97. View at Google Scholar | View at Publisher

Munyengabe, S., H. Haiyan, Z. Yiyi and S. Jiefei, 2017. Factors and levels associated with lecturers' motivation and job satisfaction in Chinese university. Eurasia Journal of Mathematics, Science and Technology Education, 13(10): 6415-6430. View at Google Scholar View at Publisher

Muoka, M.V., 2007. The role head teachers in instructional supervision in public secondary schools. Unpublished Master's Thesis, University of Nairobi, Kenya.

Mustafa, M. and N. Othman, 2010. The effect of work motivation on teacher's work performance in Pekanbaru senior high schools, Riau Province, Indonesia. Sosiohumanika, 3(2): 259-272.

Musungu, L.L. and J.W. Nasongo, 2008. The head-teacher's instructional role in academic achievement in secondary schools in Vihiga district, Kenya. Educational Research and Review, 3(10): 316-323. View at Google Scholar

Nahavandi, A., R.B. Denhardt, J.V. Denhardt and M.P. Aristigueta, 2014. Organizational behavior. London: SAGE Publications.

Nelson, D. and J. Quick, 2012. Organizational behavior: Science, the real world, and you. 8th Edn., Ohio, OH: Cengage Learning.

Oduro, G., 2008. Increased enrolment does not mean quality education (Electronic Version). Ghana News Agency.

Okendu, J.N., 2012. The influence of instructional process and supervision on academic performance of secondary school students of River State, Nigeria. Academic Research International Journal, 3(1): 147-151. 
Okumbe, J.A., 1999. Educational management. Nairobi: Nairobi University Press.

Onyambu, C., 2014. Analysis of the effect of teacher motivation on KCSE performance: A case of Masimba division, Masaba South district, Kenya. Master of Education Dissertation, Kenyatta University, Kenya.

Orodho, J.A., 2009. Elements of education and social science research methods. Maseno: Kenezja Publisher.

Oyewole, B.K. and G.B. Ehinola, 2014. Relevance of instructional supervision in the achievement of effective learning in Nigerian secondary schools. Global Journal of Commerce and Management Perspective, 3(3): 88-92.

Panigrahi, M.R., 2012. Implementation of instructional supervision in secondary schools: Approaches, prospects and problems. Science, Technology and Arts Research Journal, 1(3): 56-57. View at Google Scholar

Parahoo, K., 2006. Nursing research principles, process and issues. 2nd Edn., Hampshire: Palgrave Macmillan.

Peck, R., C. Olsen and J. Devore, 2008. Introduction to statistics and data analysis. 3rd Edn., California: Thomson Brooks/Cole.

Pinder, C.C., 2014. Work motivation in organizational behavior. 2nd Edn., New York: Taylor \& Francis.

Polit, D.F. and C.T. Beck, 2010. Essentials of nursing research: Appraising evidence for nursing practice. 8th Edn., Philadelphia: Wolters Kluwer Health Lippincott Williams \& Wilkins.

Sabitu, A.O. and A.C. Ayandoja, 2012. Impact of selected modes of instructional supervision activities on students' academic performance in senior secondary schools in Ondo state, Nigeria. Educational Research Journal, 2(1): 1- 6. View at Google Scholar

Samoei, C.J., 2014. Instructional supervisory role of principals and its' influence on students' academic achievement in public secondary schools in Nandi North District, Nandi County Kenya. Unpublished Master of Education Thesis, Catholic University of Eastern Africa.

Sergiovanni, T.J., 2009. The principalship: A reflective practice perspective. Boston: Pearson Educational Inc.

Sergiovanni, T.J. and R. Starratt, 2007. Supervision: A redefinition. 9th Edn., New York: MacGraw-Hill.

Sullivan, S. and J. Glanz, 2009. Supervision that improves teaching: Strategies and techniques. California: Corwin Press.

Thomas, H.P., 2011. Supervisory practices in non-formal educational settings as perceived by agricultural education teachers: A national study. Dissertation Paper, Iowa State University, Ames, Iowa. ProQuest LLC UMI 455312.

Wanzare, Z., 2012. Instructional supervision in public secondary schools in Kenya. Educational Management, Administration and Leadership, 4O(2): 188-2 16. View at Google Scholar $\mid$ View at Publisher

Yukl, G., 2010. Leadership in organizations. New Jersey: Prentice Hall. 